\title{
Variability of rainfall in Suriname and the relation with ENSO-SST and TA-SST
}

\author{
R. J. Nurmohamed and S. Naipal \\ University of Suriname, Paramaribo, Suriname \\ Received: 21 March 2005 - Revised: 14 December 2005 - Accepted: 15 December 2005 - Published: 9 January 2006
}

\begin{abstract}
Spatial correlations in the annual rainfall anomalies are analyzed using principle component analyses (PCA). Cross correlation analysis and composites are used to measure the influence of sea surface temperatures anomalies (SSTAs) in the tropical Atlantic and tropical Pacific Ocean with the seasonal rainfall in Suriname. The spatial and time variability in rainfall is mainly determined by the meridional movement of the Inter-tropical Convergence Zone (ITCZ). Rainfall anomalies tend to occur fairly uniformly over the whole country. In December-January (short wet season), there is a lagged correlation with the SSTAs in the Pacific region $\left(c_{\text {lag3 } 3}^{\text {Nino1+2 }}=-0.63\right)$. The strongest correlation between the March-May rainfall (beginning long wet season) and the Pacific SSTAs is found with a correlation coefficient of $c_{k}^{\text {Nino1 }+2}=0.59$ at lag 1 month. The June-August rainfall (end part of long wet season) shows the highest correlation with SSTAs in the TSA region and is about $c=-0.52$ for lag 0 . In the September-November long dry season there is also a lagged correlation with the TSA SSTAs of about $c_{\text {lag } 3}=0.66$. The different correlations and predictors can be used for seasonal rainfall predictions.
\end{abstract}

\section{Introduction}

Climate variability in north and northeast South America, except for the orography, land-sea interactions and land processes, is also linked to oceanic and atmospheric processes in the tropical Atlantic (TA) and the tropical Pacific. The most important phenomena on inter-annual to decadal time scale in this region are the Pacific El Niño-Southern Oscillation (ENSO), the Atlantic zonal equatorial mode (or the "tropical Atlantic Niño") and the tropical Atlantic meridional gradient (TAMG) (or the "tropical Atlantic dipole index") (Berlage, 1957; Giannini et al, 2000; Marshall et al., 2001; Martis et al., 2002; Rajagopolan et al., 1997; Robertson and Mechoso,

Correspondence to: R. J. Nurmohamed

(r.nurmohamed@uvs.edu)
2002; Villwock, 1998; Wang, 2001, 2005). The above phenomena are caused by the variability in sea surface temperatures (SSTs), trough the anomalies in sea level pressure and winds (Ambrizzi et al., 2005).

Garzoli et al. (1999), Giannini et al. (2000), Marshall et al. (2001) and Villwock (1998) have shown that the rainfall in northern South America is more related to the SSTAs in the tropical North Atlantic (TNA) than to the tropical South Atlantic (TSA) and the tropical Pacific ENSO. Warmer than normal SSTs in the TNA and colder than normal in the TSA correspond with weaker (stronger) than normal northeasterly (southeasterly) trade winds in the TNA and a northward displacement in the ITCZ during March-May. This causes an increase in rainfall in this region. During the Pacific ENSO, below normal precipitation is experienced in northern South America during December-February and MarchMay (Ropelewski and Hapert, 1987, 1989, 1996). During La Niña events, above normal precipitation is experienced during the same period in northern South America (Acevedo et al., 1999; Turner, 2004). The Atlantic Niño is similar but weaker than the Pacific Niño. Wang $(2001,2005)$ defined the tropical Atlantic dipole and showed that it is correlated with the north-south displacement of the ITCZ (Wang, 2005).

In this paper, an attempt is made to analyze the variability of the rainfall in Suriname $\left(2-6^{\circ} \mathrm{NB} ; 54-58^{\circ} \mathrm{WL}\right)$ and the relationship between the Atlantic and Pacific SSTs. The datasets used and the methods are described in Sect. 2. Section 3 contains the results and discussions and the conclusions are included in Sect. 4.

\section{Data and methods}

Twelve rainfall gauge stations distributed throughout Suriname that contain sufficient data are used to characterize the climate variability across Suriname (Fig. 1). The meteorological data is provided by the Meteorological Service Suriname (MDS). For the classification of the spatial features of the annual cycle of rainfall (1961-1985) in 


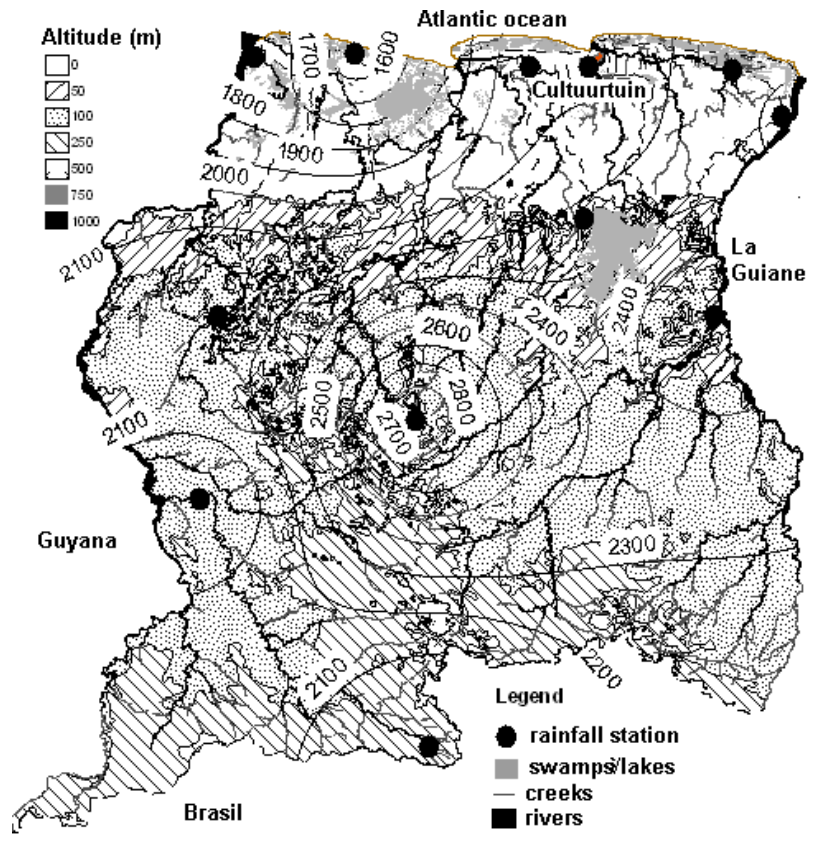

Fig. 1. Contour map of annual precipitation totals $(\mathrm{mm})$ in Suriname, 1961-1985. Note: the circles show the location of the rainfall station.

Suriname, the correlation between the average of all the stations and each station is calculated. Principle component analysis (PCA) of the annual rainfall anomalies is also calculated using the Climate Predictability Tool (v.5.04) of the International Research Institute for Climate Prediction IRI (http://iri.columbia.edu/outreach/software/). The Chi-square goodness-of-fit test has shown that the monthly precipitation data (1961-1985) at the stations, except for Moengo, are normally distributed.

To investigate the relationship between the rainfall anomalies in Suriname and the Atlantic and Pacific SSTAs on inter-annual scale, cross correlation analyses and composites are used. For this purpose, only 7 rainfall stations are used. These analyses are carried out on seasonal scale (December-February DJF; March-May MAM; June-August JJA; September-November SON), using the Anclim model (Stipanek, 2003) and the KNMI Climate Explorer (http: //climexp.knmi.nl/). Monthly observed SSTs (1950-2003) are adapted from the National Oceanic and Atmospheric Administration (NOAA-CIRES Climate Diagnostics Center, $2004)$ for the tropical northern Atlantic-TNA $\left(5.5^{\circ}-23.5^{\circ} \mathrm{N}\right.$, $\left.15^{\circ}-57.5^{\circ} \mathrm{W}\right)$, the tropical southern Atlantic-TSA $\left(0^{\circ}-20^{\circ} \mathrm{S}\right.$, $\left.10^{\circ} \mathrm{E}-30^{\circ} \mathrm{W}\right)$, the Extreme Eastern tropical Pacific ENSONiño $1+2\left(0^{\circ}-10^{\circ} \mathrm{S}, 90^{\circ}-80^{\circ} \mathrm{W}\right)$ and East Central Pacific ENSO-Niño $3+4\left(5^{\circ} \mathrm{N}-5^{\circ} \mathrm{S}, 160^{\circ} \mathrm{E}-150^{\circ} \mathrm{W}\right)$. The monthly Atlantic Niño SSTAs $\left(3^{\circ} \mathrm{S}-3^{\circ} \mathrm{N}, 20^{\circ} \mathrm{W}-0^{\circ}\right)$ and SSTAs in the tropical Atlantic ("dipole index") are obtained from Dr. Wang, C. (NOAA). The Atlantic dipole is defined as the difference between the SSTAs in the TNA $\left(5.5^{\circ}-23.5^{\circ} \mathrm{N}\right.$, $\left.15^{\circ}-57.5^{\circ} \mathrm{W}\right)$ and the SST anomalies in the TSA $\left(0^{\circ}-20^{\circ} \mathrm{S}\right.$, $10^{\circ} \mathrm{E}-30^{\circ} \mathrm{W}$ ) (Wang, 2001). For the uniformity and availability of statistical tables, statistical tests in this study are performed at a 5\% significance level.

\section{Results and discussion}

\subsection{Variability of rainfall}

Figure 1 shows the distribution of the annual precipitation (1961-1985) based on twelve rainfall stations. A main feature of the precipitation distribution is that the annual precipitation is the highest in the mountainous area of Suriname (center of Suriname: about $2800 \mathrm{~mm}$ ) and the lowest in the low-lying areas (northwest Suriname: about $1650 \mathrm{~mm}$ ). The season rainfall distribution has the same pattern as the annual rainfall distribution. Figure $2 \mathrm{a}$ shows that there is a relatively high correlation $(r>0.60)$ between the rainfall stations. In general, the PCA results (Fig. 2b) also shows that the annual rainfall anomalies tend to occur fairly uniformly across the whole country. The first empirical orthogonal function (EOF) represents about 50\% variance, which can be explained by the weak correlation at Brownsweg (0.47), Nw.Nickerie (0.55) and Groningen (0.57). Figure 2c shows the inter-annual variability with the temporal scores from which can be concluded that 1964 was a very dry year and 1976 a very wet year. In the next paragraph the seasonal spatial variability of rainfall will be discussed further.

\subsection{Relationship between rainfall anomalies and Atlantic and Pacific SSTAs}

Figure 3 shows the observed monthly SSTs in the different regions and the monthly observed rainfall at station Cultuurtuin. The monthly rainfall shows a seasonal cycle, which is caused by the meridional movement of the Inter-tropical Convergence Zone (ITCZ). The monthly rainfall is the highest in May-June and the lowest in October-September. Most of the other rainfall stations also show a similar seasonal rainfall pattern.

Figure 4 shows the lagged correlation (Pearson's coefficient) of the DJF, MAM, JJA and SON precipitation anomalies at station Cultuurtuin with the SSTAs in the TNA, TSA, Niño 1+2, Niño 3+4, Atlantic Niño and the TA dipole region. Because of the fact that all the rainfall stations show similar results, only station Cultuurtuin will be used further in this study. During December-February (the short wet season), the TNA is less warmer than normal and the TSA is warmer than normal (Fig. 5). Northeasterly trade winds north of the equator are strengthened, while the southeasterly trade winds south of the equator are weakened (Villwock, 1998; Webster, 2005). In DJF, the precipitation anomalies show a much stronger correlation with the SSTAs in the Niño $1+2$ region $\left(c_{\text {lag } 3}=-0.63\right)$, followed by the tropical Atlantic Niño region $\left(c_{\mathrm{lag} 0}=-0.36\right)$ and the TA region $\left(c_{\operatorname{lag} 0}=-0.32\right)$. Correlations with the SSTAs in the TNA region $\left(c_{\operatorname{lag} 11-12}=0.23\right)$ and the SSTAs in the TSA region $\left(c_{\mathrm{lag} 3}=-0.24\right)$ are lower (Fig. $4 \mathrm{a}$, $b, f)$. During DJF, the ITCZ has a small rainfall belt and 


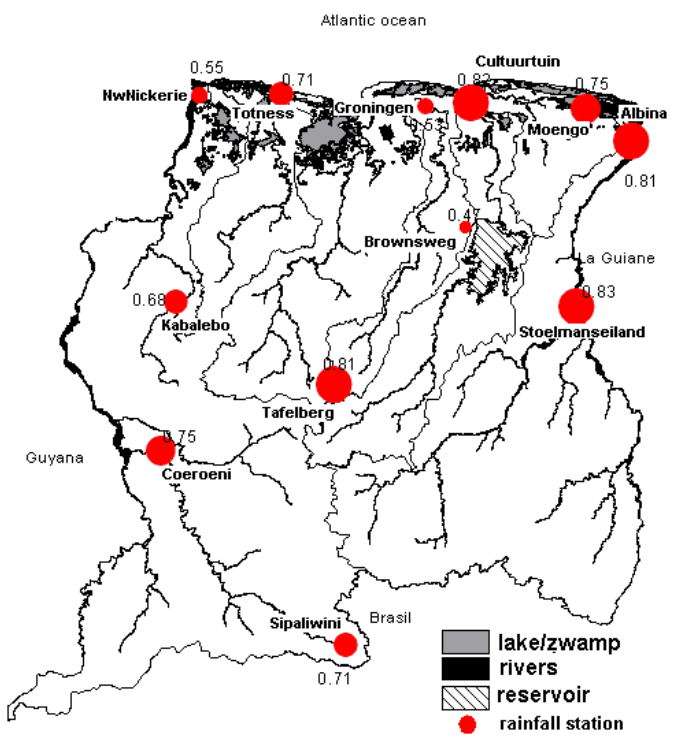

(a)
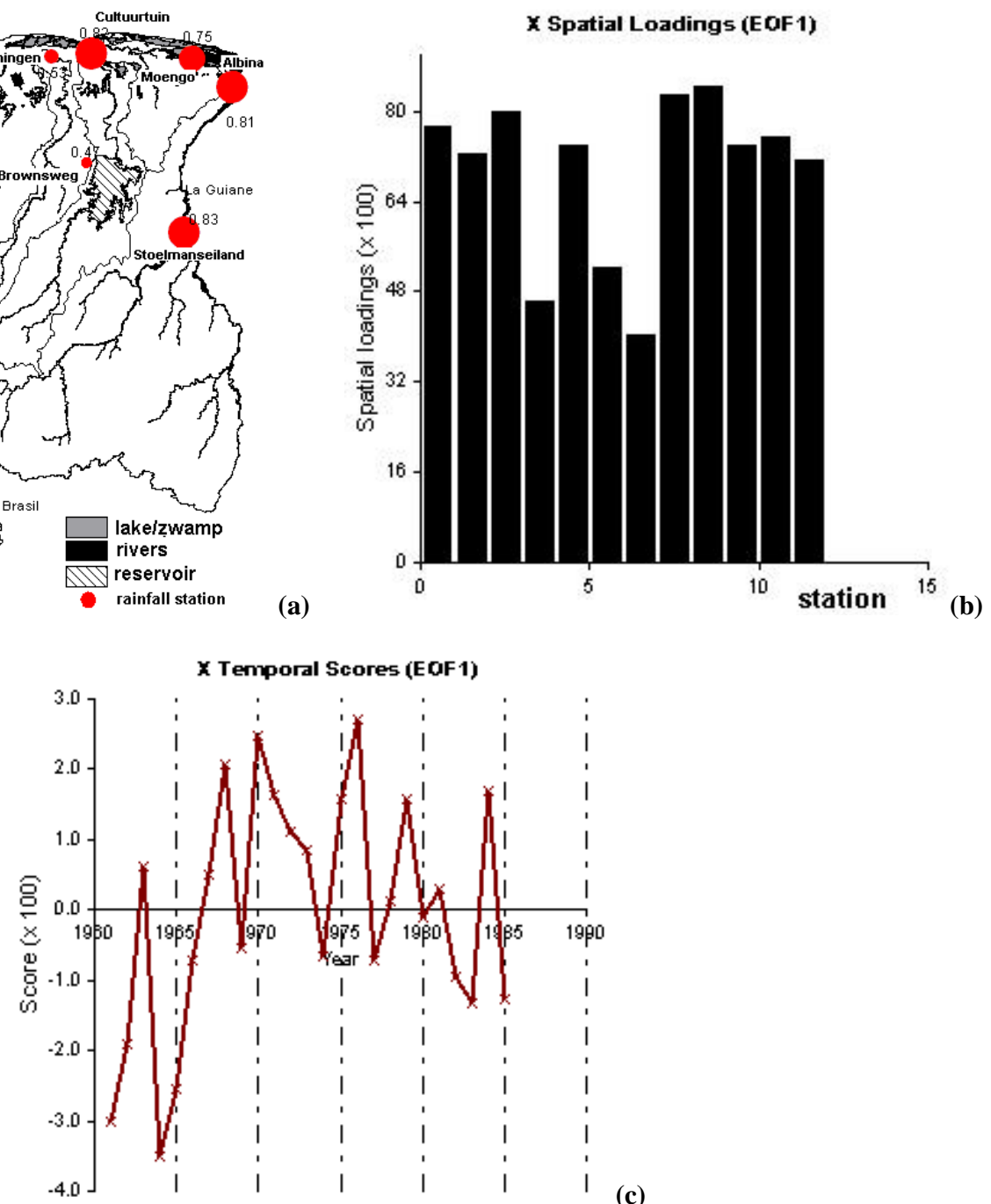

(c)

Fig. 2. (a) Correlation of the annual rainfall between each rainfall station and the average of all the stations (Pearson's coefficient, $5 \%$ level of significance), (b) spatial loadings (EOF 1) of the annual rainfall anomalies at 12 rainfall stations, (c) temporal scores (EOF 1). Note: station 1=Albina; $2=$ Moengo; $3=$ Cultuurtuin; $4=$ Groningen; $5=$ Friendship-Totness; $6=$ Nw. Nickerie; $7=$ Brownsweg; $8=$ Stoelmanseiland; 9=Tafelberg; 10=Sipalwini; 11=Coeroeni; 12=Kabalebo.

is displaced southward of Suriname and causes a reduction in precipitation across Suriname that reaches its peak during February-March. February-March is the short dry season.

During April-mid August (the long wet season) the TNA (TSA) becomes warmer (colder) than normal indicating a northward movement of the ITCZ. Oceanic air rises over the TNA warm water, easterly trade winds from the Atlantic Ocean are weakened north of the equator and easterly trade winds south of the equator increase. The southeasterly trade winds also bring the tropical heat sources of the Amazon to Suriname. Evaporation increases over the TNA and as a result precipitation increases over northern South America. During this period, the ITCZ has a rainfall belt that is twice the rainfall belt during DJF and hardly covers the whole of Suriname. The extension of this season compared to the small wet season is due to the fact that the ITCZ collides with the relief of the country (near Tafelberg) as well with the south and northeast trade winds, which causes its movement to become slower. This explains the high rainfall in the center of Suriname (Fig. 1). During the beginning of the long wet season (MAM), the Niño 1+2, TSA and the tropical Atlantic Niño SSTAs show all a strong correlation with the rainfall anomalies in the same order of magnitude of about $c_{\text {lag1 }}^{N i n o 1+2}=0.59$, $c_{\text {lag0 }}^{T S A}=-0.52$ and $c_{\text {lag0 }}^{\text {Atlantic Nino }}=-0.52$, than with the TNA SSTAs $\left(c_{\mathrm{lag} 0}=0.23\right)$ and the TA dipole SSTAs $\left(c_{\operatorname{lag} 7}=0.33\right)$ (Fig. 4). During JJA, the SSTAs in both the TA dipole and TSA region show a stronger correlation with the rainfall anomalies than in the other regions of $c_{\operatorname{lag} 10}=-0.49$ and $c_{\text {lag } 0}=-0.52$ respectively. 


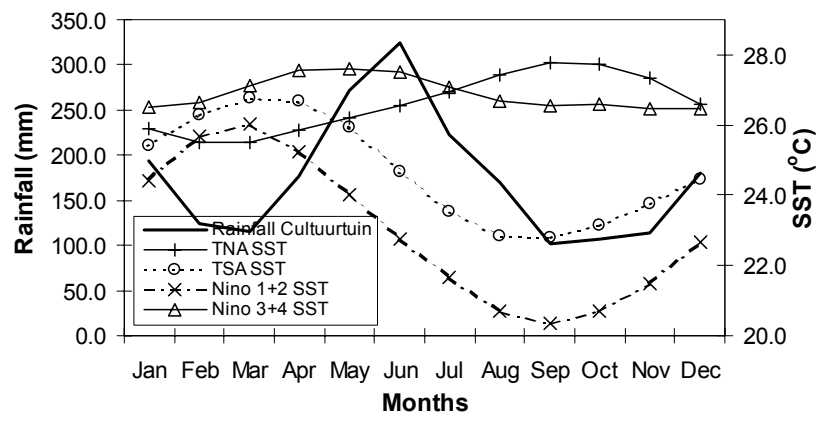

Fig. 3. Monthly variation of observed SSTs in the TNA, TSA, Niño $1+2$ and Niño 3+4 regions and the observed monthly rainfall at $\mathrm{Cul}-$ tuurtuin (Paramaribo) for the period 1961-1985.

From mid-August to November (the long dry season), the SSTs in the TNA (TSA) are the highest (lowest) and the precipitation maximum has passed over Suriname and is found north $\left(5-10^{\circ} \mathrm{N}\right)$ above the Atlantic Ocean (Webster, 2005). During this period, the trade winds south of the equator increase surface winds and cause surface evaporative cooling and, as a result, less rainfall above Suriname. The rainfall anomalies show the largest positive correlation with the SSTAs in the TSA region $\left(c_{\operatorname{lag} 3}=0.66\right)$ and the Atlantic Niño region $\left(c_{\mathrm{lag} 4}=0.63\right)$ than in the other regions.

Cross correlation analyses have shown that the Pacific Niño 3+4 SSTAs shows a stronger correlation with the TNA SSTAs during all the seasons compared to the Niño 1+2 SST. The highest correlation is reached in MAM and is 0.72 for $k=4$ months. In the TSA region, the Niño $1+2$ SST is slightly stronger correlated with the SST than the Niño 3+4 SST. The highest correlation $\left(c_{k}=0.44\right)$ is obtained when the Niño $1+2$ SSTAs lead the TSA SSTAs by 4,8 and 12 months in DJF, MAM and JJA respectively. Similar results were also found by Wang (2001) and Marshall et al. (2001).

\section{Conclusions}

Analysis of spatial variability of rainfall (1961-1985) has shown that the highest annual rainfall is found in the central area of Suriname and the lowest annual rainfall along the coastal area in northeast Suriname. There exist a medium to high correlation in the annual rainfall variability between the different stations: 0.47 at Brownsweg up to 0.83 at Stoelmanseiland. A decreasing trend in annual precipitation occurs in central and southwest Suriname (maximum $-14.5 \mathrm{~mm}$ year $^{-1}$ ), while a rising trend is observed in the other areas of Suriname. The highest negative trend is in northeast Suriname and is about $42.7 \mathrm{~mm}_{\text {year }}{ }^{-1}$. The highest rainfall occurs at all the stations in May-June and the lowest rainfall in October-September.

Statistical analyses of rainfall in Suriname show that rainfall (station Cultuurtuin), during the short wet season (DJF), is linearly correlated with the Pacific SSTAs in the Niño $1+2$ region three months earlier with a correlation coeffi- cient of $c_{k}=-0.63$. The MAM rainfall anomaly (beginning long wet season) correlate with the TA SSTAs $\left(c_{\operatorname{lag} 0}^{T S A}=-0.52\right.$; $\left.c_{\text {lag0 }}^{\text {Atlantic Nino }}=-0.52\right)$ as well as with the Pacific SSTAs $\left(c_{\text {lag1 }}^{\text {Nino1 }}=0.59\right)$. The highest correlation between the JJA rainfall (long wet season) and the SSTAs is reached in the TSA region and is about $c=-0.52$ for lag 0 . Finally, the long dry season (SON) is stronger correlated with the TSA SSTAs $\left(c_{\text {lag } 3}=0.66\right)$. For all seasons it is found that the rainfall is also medium to highly correlated with the Pacific SSTAs, which indicates that El Niño events may cause rainfall below or above normal (drought conditions). The correlation with the Niño $1+2$ SSTAs is stronger during DJF $\left(c_{\text {lag } 3}=-0.63\right)$, followed by MAM $\left(c_{\operatorname{lag} 1}=0.59\right), \mathrm{SON}\left(c_{\operatorname{lag} 0}=-0.57\right)$ and JJA $\left(c_{\text {lag0-1 }}=-0.52\right)$.

The knowledge of rainfall variability and processes responsible for this variability, among other things, is used to provide scenarios that can be used for water resources planning and design of hydraulic works. At present, forecasting the Atlantic climate variability and the Pacific ENSO with respect to rainfall need to be further examined. More research is needed to advance our understanding of the tropical oceanic and atmospheric processes, the interactions and the mechanisms of variability in Suriname and surrounding countries.

Acknowledgements. This work was partially financially supported by the Research and Development Fund of the University of Suriname. The main author would like to thank C. Wang, G. Alessandra and G. van Oldenborgh for their cooperation. Two anonymous reviewers provided valuable comments that helped improve the manuscript.

Edited by: P. Fabian and J. L. Santos

Reviewed by: two anonymous referees

\section{References}

Acevedo, M., McGregor, K., Andressen, R., Ramirez, H., and Ablan, M.: Relations of climate variability in Venezuela to tropical pacific SST anomalies, 10th Symposium on Global Change Studies, America Meteorological Society, preprints pp. 81-84, Annual Meeting, Dallas, TX, 1999.

Ambrizzi, T., de Souza, E. B., and Pulwarty, R. S.: The Hadley and Walker regional circulations and associated ENSO impacts on South American seasonal rainfall, in: The Hadley Circulation: present, past and future, edited by: Diaz, H. F. and Bradley, R. S., Kluwer Academic Publishers, Netherlands, 203-231, 2005.

Berlage, H. P.: Fluctuations of the general atmospheric circulation of more than one year, their nature and prognotisc value, Koninklijk Nederlands Meteorologisch Instituut, Mededelingen en Verhandelingen, 69, pp. 152, 1957.

Emanuels, J.: Klassificatie der seizoenen, serie 2, no 6, Meteorologische Dienst, Ministerie van Bouwwerk, Verkeer en Waterstaat, Suriname, 1-14, 1968.

Gianninni, A., Kushnir, Y., and Cane, M.: Interannual variability of Caribbean rainfall, ENSO and the Atlantic Ocean, J. Clim., 13, 297-311, 2000. 


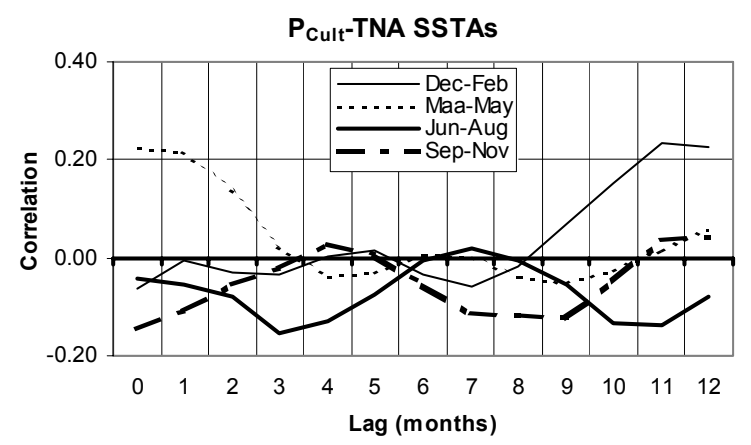

(a)

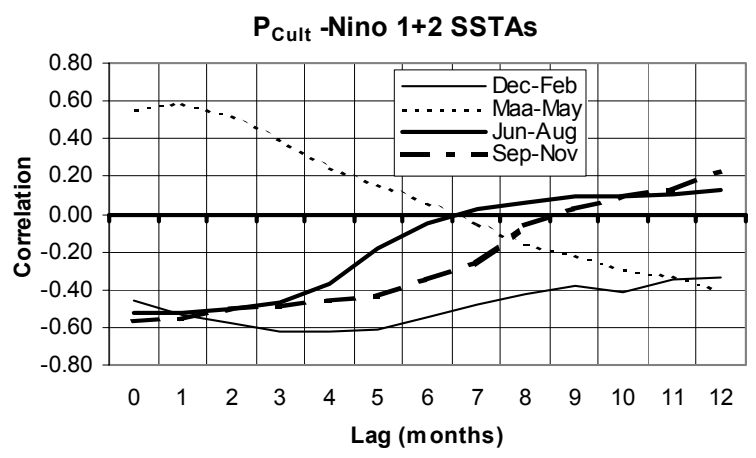

(c)

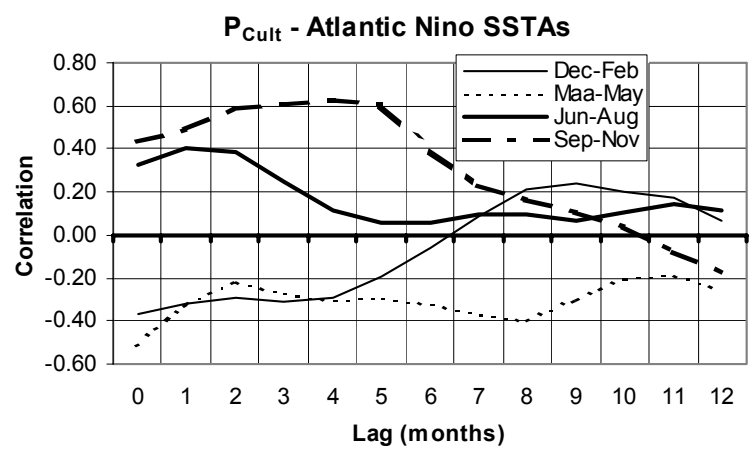

(e)

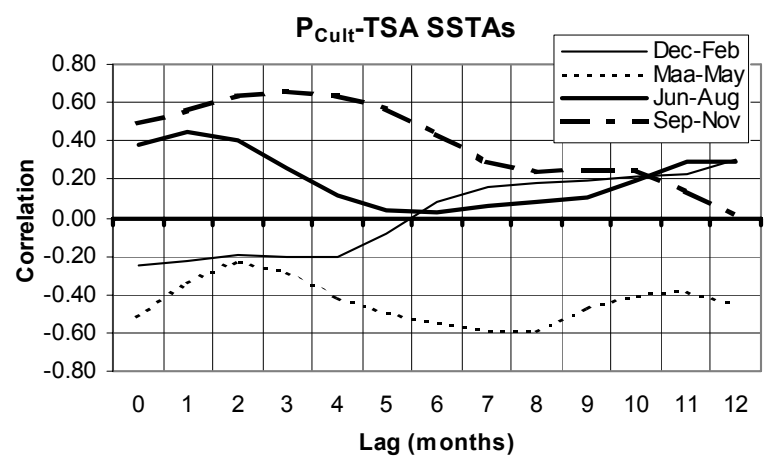

(b)
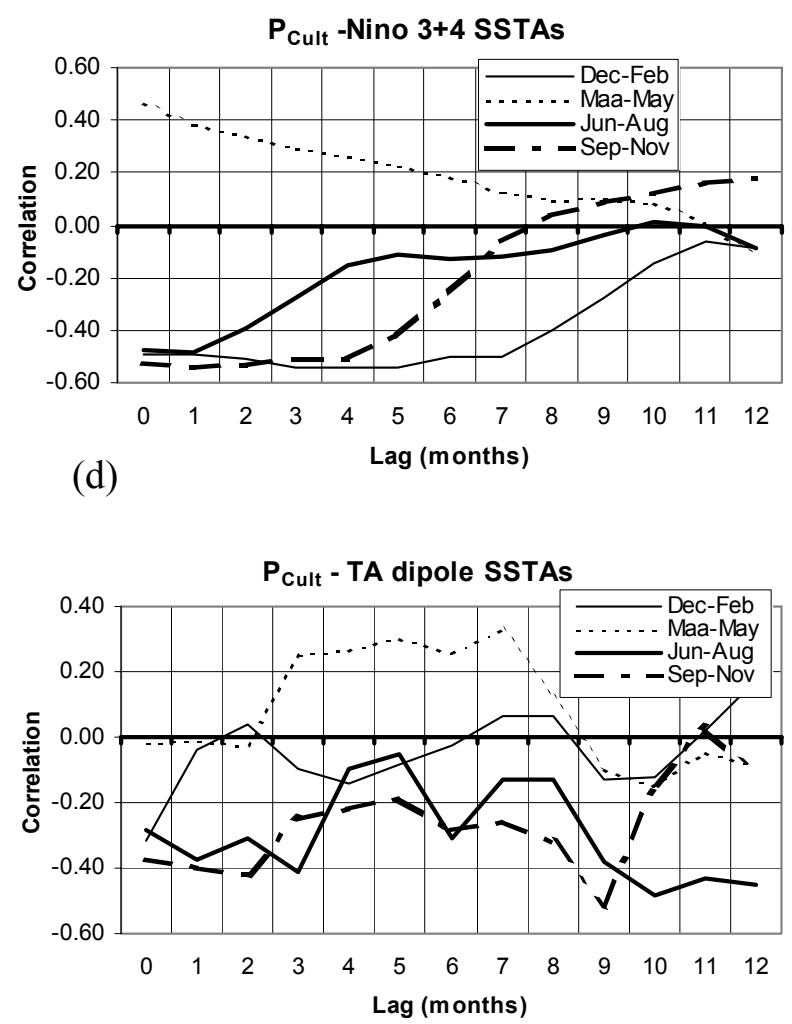

(f)

Fig. 4. Lag correlation coefficient of the precipitation anomalies (1961-1985) at station Cultuurtuin for December-February (DJF), MarchMay (MAM), June-August (JJA) and September-November (SON) with the (a) TNA SSTAs, (b) TSA SSTAs, (c) Niño 1+2 SSTAs, (d) Niño 3+4 SSTAs, (e) Atlantic Niño SSTAs and (f) tropical Atlantic dipole SSTAs. Note: lag positive, SSTAs leading index.

Martis, A., van Oldenburg, G. J., and Burgers, G.: Predicting rainfall in the Dutch Caribbean - more than El Nino?, Int. J. Climatol., 22, 1219-1234, 2002.

Marshall, J., Kushnir, Y., Battisti, D., Change, P., Czaja, A., Dickson, R., Hurrel, J., McCartney, M., Saravanan, R., and Visbeck, M.: North Atlantic Climate Variability: phenomena, impacts and mechanism, Int. J. Climatol., 21, 1863-1898, 2001.

Martis, A., van Oldenberg, G., and Burgers, G.: Predicting rainfall in the Dutch Caribbean-more than El Niño?, Int. J. Climatol., 22, 1219-1234, 2002.

NOAA-CIRES Climate Diagnostics Center: Climate Indices: Monthly Atmospheric and Ocean Time Series, Retrieved $7 \mathrm{Au}-$ gust 2004 from http://www.cdc.noaa.gov/ClimateIndices/, 2004.
Rajagopolan, B., Kushir, Y., Tourre, Y., and Cane, M.: Temporal Variability of North Atlantic Oscillation and Tropical Atlantic SST, Lamont-Doherty Earth Observatory of Columbia University, New York, 1997.

Robertson, A. and Mechoso, C.: Links between the American Ocean and the South American Climate Variability, CLIVAR Exchanges, 25, 12-15, 2002.

Ropelewski, C. F. and Halpert, M. S.: Global and regional precipitation patterns associated with the El Niño/Southern Oscillation, Mon. Wea. Rev, 115, 1606-1626, 1987.

Ropelewski, C. F. and Halpert, M. S.: Precipitation patterns associated with the high index phase of the Southern Oscillation, J. Clim., 2, 268-284, 1989. 
Ropelewski, C. F. and Halpert, M. S.: Quantifying Southern Oscillation-precipitation relationships, J. Clim., 9, 1043-1059, 1996.

Turner, J.: The El Niño-Southern Oscillation and Antarctica, Int. J. Climatal., 24, 1-31, 2004.

Villwock, A.: Clivar Initial Implementation Plan, retrieved 27 March 2004 from www.clivar.com/publications/othre_pubs/ iplan/iip/pd2.htm, 1998.

Wang, C.: Atlantic climate variability and its associated atmospheric circulation cells, Int. J. Clim., 15, 1516-1536, 2001.
Wang, C.: ENSO, Atlantic climate variability, and the Walker and Hadley circulations, in: The Hadley Circulation: present, past and future, edited by: Diaz, H. F. and Bradley, R. S., Kluwer Academic Publishers, Netherlands, 173-202, 2005.

Webster, P. J.: The elementary Hadley circulation, in: The Hadley Circulation: present, past and future, edited by: Diaz, H. F. and Bradley, R. S., Kluwer Academic Publishers, Netherlands, 9-60, 2005 . 